CrossMark
Dostępne online www.journals.wco.pl/los
Zeszyty Naukowe WCO, Letters in Oncology Science 2019;16(2):88-94

Dostępne online www.journals.wco.pl/los
Zeszyty Naukowe WCO, Letters in Oncology Science 2019;16(2):88-94

Praca poglądowa/Review paper

\section{Letters in Zncology Science}

ISSN 2543-6724

ZESZYTY NAUKOWE WIELKOPOLSKIEGO CENTRUM ONKOLOGII

\title{
Rola układu immunologicznego w patogenezie oraz progresji płaskonabłonkowego raka głowy i szyi
}

\section{The role of the immune system in pathogenesis and progression of head and neck squamous cell carcinoma}

\author{
Natalia Maćkowska ${ }^{1,2}$, Agnieszka Sobecka ${ }^{1,2, *}$, \\ Wojciech Golusiński², Wiktoria M. Suchorska ${ }^{1,3}$ \\ ${ }^{1}$ Pracownia Radiobiologii, Zakład Fizyki Medycznej, Wielkopolskie Centrum Onkologii, ul. Garbary 15, 61-866 Poznań \\ ${ }^{2}$ Katedra i Klinika Chirurgii Głowy, Szyi i Onkologii Laryngologicznej, Uniwersytet Medyczny w Poznaniu, \\ Wielkopolskie Centrum Onkologii, ul. Garbary 15, 61-866 Poznań \\ ${ }^{3}$ Katedra i Zakład Elektroradiologii, Uniwersytet Medyczny w Poznaniu, Wielkopolskie Centrum Onkologii,
}

\section{Streszczenie}

Płaskonabłonkowy rak głowy i szyi (HNSCC, ang. Head and Neck Squamous Cell Carcinoma) to nowotwór wywodzący się z komórek płaskonabłonkowych błon śluzowych jamy ustnej, nosa lub gardła. Pomimo znacznych postępów konwencjonalnych metod leczenia, 5-letni wskaźnik przeżycia bez progresji u pacjentów z miejscowo zaawansowanym HNSCC HPV(-) nadal nie przekracza 50\%. Niskie wskaźniki przeżycia w połączeniu z wysoką toksycznością stosowanych terapii, podkreślają konieczność wprowadzenia nowych strategii terapeutycznych. Obecne badania potwierdzają, że układ immunologiczny odgrywa kluczową rolę w patogenezie HNSCC. Lepsze zrozumienie mechanizmów molekularnych odpowiedzialnych za ucieczkę komórek nowotworowych spod kontroli układu immunologicznego oraz dokładne poznanie szlaków molekularnych odpowiedzialnych za rozwój płaskonabłonkowego raka głowy i szyi umożliwi opracowanie bardziej efektywnych terapii. Celem pracy jest przegląd wiedzy dotyczącej roli układu odpornościowego w ucieczce komórek nowotworowych HNSCC spod nadzoru immunologicznego.

Adres do korespondencji

mgr inż. Agnieszka Sobecka

Pracownia Radiobiologii,

Wielkopolskie Centrum Onkologii, ul. Garbary 15, 61-866 Poznań, Polska

Telefon. +48618850474

e-mail: agnieszka.sobecka@wco.pl 


\begin{abstract}
Head and neck squamous cell carcinoma (HNSCC) takes origin from squamous cells of mucous membranes of the mouth, nose and throat. Despite significant advances in conventional therapies, the 5-year progressionfree survival rate in patients with locally advanced HNSCC HPV (-) still does not exceed 50\%. Low survival rate in combination with high toxicity of used therapies underline the necessity of introducing new therapeutic strategies. Current research confirms that the immune system plays a key role in the pathogenesis of HNSCC. Better understanding of molecular mechanisms responsible for the immune evasion of cancer cells and exact investigation of molecular pathways responsible for HNSCC development could help to develop more effective therapies. Considering the fact that in HNSCC course there are significant changes in the molecular mechanisms of the immune system. In this review we summarize the role of immune system in immunesurveillance escape of tumour cells
\end{abstract}

Słowa kluczowe: immunoterapia, rak płaskonabłonkowy głowy i szyi, terapia nowotworów

Keywords: immunotherapy, head and neck squamous cel carcinoma, cancer therapy

\title{
Wstęp
}

Płaskonabłonkowy rak regionu głowy i szyi (HNSCC ang. Head and Neck Squamous Cell Carcinoma) jest jednostką chorobową zlokalizowaną w istotnych okolicach anatomicznych, takich jak: jama ustna, jama nosowo-gardłowa oraz krtań [1]. Pod wspólną nazwą występują nowotwory o różnym podłożu etiologicznym [2]. HNSCC stanowi szóstą pod względem częstości występowania chorobę nowotworową na świecie. Rocznie odnotowuje się 550 tysięcy zachorowań oraz około 300 tysięcy zgonów. Około 90\% wszystkich nowotworów regionu głowy i szyi wywodzi się z komórek płaskonabłonkowych [3, 4]. Występowanie tych nowotworów jest silnie związane z czynnikami środowiskowymi oraz stylem życia pacjentów. Badania wykazały, że ekspozycja na kancerogeny, takie jak dym tytoniowy czy alkohol, znacznie podwyższa prawdopodobieństwo zachorowania na HNSCC. Do biologicznych czynników ryzyka należy zakażenie wirusem brodawczaka ludzkiego (HPV, ang. Human Papilloma Virus), szczególnie typem HPV16 i HPV18. HNSCC HPV (+) jest odrębną podjednostką kliniczną o bardziej korzystnym rokowaniu $[4,5,6]$.

Zaburzenia w funkcjonowaniu układu immunologicznego odgrywają kluczową rolę w rozwoju chorób nowotworowych, w tym płaskonabłonkowego raka głowy i szyi. W przebiegu HNSCC obserwuje się znaczną reorganizację mechanizmów molekularnych [7]. Zaburzenia w funkcjonowaniu układu odpornościowego i mutacje zachodzące w transformowanych komórkach pozwalają na ucieczkę komórek spod kontroli układu immunologicznego, a w dalszej perspektywie, umożliwiają rozwój nowotworu [8]. Guz wydziela liczne cząsteczki, np. cytokiny, czy różnego rodzaju czynniki wzrostowe, które tłumią komórkową odpowiedź przeciwnowotworową [9,10]. HNSCC jest chorobą immunosupresyjną, w jej przebiegu odnotowuje się: niższą bezwzględną liczbę limfocytów [11], obecność defektywnych komórek NK (ang. Natural Killer) $[12,13]$ oraz osłabioną zdolność komórek dendrycznych do prezentowania antygenów [14, 15]. Status układu odpornościowego w wielu przypadkach decyduje o pojawieniu się nowotworu [8]. W prawidłowo funkcjonującym organizmie „nadzór immunologiczny” stanowi skuteczny mechanizm powstrzymujący rozwój guza, jednak zaburzenia w działaniu układu odpornościowego umożliwiają rozwój HNSCC zarówno HPV (+) jak i HPV(-) [16]. Chorzy z zespołem nabytego niedoboru odporności (AIDS, ang. Acquired Immunodeficiency Syndrome) wykazują 2-6 razy wyższe ryzyko rozwoju HNSC [17, 18]. Dowiedziono również, że przyjmowanie leków immunosupresyjnych, wyciszających działanie układu immunologicznego, wpływa na zwiększenie częstości występowania raka płaskonabłonkowego w głowy i szyi [19]. Status układu odpornościowego chorych z HNSCC nie jest interesujący tylko z perspektywy naukowej, ale w przyszłości może on również mieć charakter prognostyczny [20].

Celem tej pracy jest omówienie udziału układu immunologicznego w patogenezie i progresji płaskonabłonkowego raka głowy i szyi. 


\section{Zaburzenia działania głównego systemu zgodności tkankowej (MHC) w przebiegu HNSCC}

Zaproponowana przez Thomasa i Burnetta teoria „nadzoru immunologicznego” zakłada, że układ odpornościowy rozpoznaje oraz eliminuje powstające komórki nowotworowe [21]. Aby doszło do efektywnej odpowiedzi immunologicznej konieczne jest wystąpienie kilku symultanicznych sygnałów. Kluczowa jest interakcja pomiędzy kompleksem ludzkich antygenów leukocytarnych (HLA, ang. Human Leukocyte Antigen), a receptorem komórek T (TCR, ang. T-cell Receptor) oraz immunoaktywacja cytokin, takich jak interleukina 2 (IL-2) oraz interferon- $\gamma$ (IFN- $\gamma$ ). Ponadto do wymienionych sygnałów należy dodać szereg reakcji kostymulujących i koinhibitorowych, które warunkują wystąpienie odpowiedzi immunologicznej oraz wpływają na jej ostateczną siłę [8].

Najważniejszym elementem w procesie rozpoznawania przez układ immunologiczny obcych lub zmienionych komórek jest kompleks ludzkich antygenów leukocytarnych (HLA, ang. Human Leukocyte Antigens). HLA prezentuje antygeny nowotworowe limfocytom T [15]. Endogenne antygeny dojrzewają w procesie wewnątrzkomórkowej degradacji proteasomalnej, następnie są transportowane do siateczki śródplazmatycznej przez transporter o nazwie TAP1/2 (ang. Transporter Associated with Antigen Processing). W retikulum fragmenty zdegradowanych białek łączą się z łańcuchami ciężkimi HLA klasy I. Aby doszło do efektywnego rozpoznania komórki nowotworowej przez układ odpornościowy wymagana jest obecność w pełni funkcjonalniej maszynerii do obróbki antygenów (APM, ang. Antigen Processing Machinery). Komórki HNSCC wykazujące ekspresję HLA I oraz neoantygenów mogą wciąż unikać odpowiedzi układu immunologicznego poprzez obniżenie ekspresji HLA oraz mutacje w maszynerii APM [22, 23]. Jednak całkowita utrata kompleksu HLA na powierzchni komórek nowotworowych nie jest dla nich korzystna, wprawdzie umożliwia ona ucieczkę przed działaniem limfocytów T, jednak brak antygenów na powierzchni komórek stanowi silny czynnik aktywujący komórki NK [24]. Z tego powodu komórki nowotworowe wykorzystują dodatkowo inne strategie umożliwiające ucieczkę spod kontroli układu immunologicznego i jednocześnie zachowanie częściowej ekspresji HLA. Oczywiście wiąże się to z pewnym ryzykiem dla komórek nowotworowych, ale również zapewnia brak aktywacji komórek NK [8].

W przebiegu HNSCC zaobserwowano występowanie mutacji zarówno w elementach kompleksu HLA (allelach kodujących $\beta-2$ mikroglobulinę, B2M), jak i w genach maszynerii obróbki antygenów [25]. Mutacje te mogą powodować defekty regulatorowe oraz selektywną utratę ekspresji HLA czy też APM [26]. Zaburzenia te skutkują osłabieniem obróbki i prezentacji antygenów nowotworowych, co umożliwia komórkom nowotworowym ucieczkę przed lizą za pośrednictwem limfocytów T oraz uniknięcie aktywacji komórek NK [25, 27, 28]. Mechanizm stojący za uszkodzeniem składników APM pozostaje wciąż nieznany, mutacje w obrębie tych genów mają znaczny wpływ na rozwój choroby i są obserwowane w 20\% przypadków HNSCC. Ponadto wykazano, że korelują z przerzutami do węzłów chłonnych oraz cięższą postacią choroby [23, 29]. Badania wykazują, że ekspresja receptora śródbłonkowego czynnika wzrostu (EGFR, ang. Epidermal Growth Factor Receptor) na powierzchni komórek guza może mieć istotne znaczenie w unikaniu rozpoznania immunologicznego. EGFR działa wykorzystując szereg onkogennych ścieżek sygnalizacyjnych, w tym wewnątrzkomórkowe szlaki angażujące kinazy aktywowane mitogenami (MAPK ang. MitogenActivated Protein Kinases). Co więcej czynnik EGFR prowadzi do supresji szlaku SHP2/STAT1 (ang. SH2 Domain-Containing Protein-Tyrosine Phosphatase/Signal Transducer and Activator of Transcription 1) oraz ścieżki sygnalizacyjnej PI3K/AKT (kinazy fosfatydyloinozytolu/kinazy Akt) [30, 31, 32]. Niedobór HLA oraz składników APM może zostać w HNSCC przywrócony do normy przez zmniejszenie ilości SHP2 w komórkach lub zastosowanie antagonisty STAT1, czyli IFN- $\gamma$. Obydwa podejścia skutkują podwyższeniem ekspresji HLA klasy I na powierzchni komórek nowotworowych, tym samym zwiększając efektywność lizy komórek nowotworowych przez limfocyty T [33, 34, 35]. Wykorzystanie czynników pobudzających sygnalizację IFN- $\gamma$ i aktywujących szlak STAT1 może przynieść znaczącą wartość terapeutyczną. Poprzez działanie tych cząsteczek nie tylko dochodzi do podwyższenia ekspresji HLA klasy I, ale również pobudzenia wydzielania cytokin prozapalnych $[33,36]$. 


\section{Punkty kontrolne układu immunologicznego w rozwoju HNSCC}

Aktywacja limfocytów T niejest stymulowana wyłącznie poprzezinterakcjęz antygenami nowotworowymi. Występuje szereg różnych sygnałów kostymulatorowych oraz koinhibitorowych, których zadaniem jest pobudzaniealbo hamowniedziałaniaukładu immunologicznego [37].Układ odpornościowy posiada takzwane punkty kontrolne, których zadaniem jest blokowanie rozwoju chorób autoimmunologicznych. Adaptacyjna odporność immunologiczna polega na hamowaniu nadmiernych reakcji ze strony układu odpornościowego. W środowisku nowotworowym dochodzi do nadekspresji hamujących punktów kontrolnych, co prowadzi do immunosupresji promującej rozwój nowotworu [24].

W kontekście immunoterapii przeciwnowotworowej można wymienić dwa bardzo dobrze poznane punkty kontrolne. Pierwszym z nich jest białko programowanej śmierci komórki PD-1 (ang. Programmed Cell Death Protein1,CD297),drugim:antygen 4związanyzlimfocytami(CTLA4, ang.CytotoxicT-Lymphocyte-Associated Antygen 4). Obydwa punkty kontrolne stanowią cel dla przeciwciał monoklonalnych zatwierdzonych przez FDA (Agencja Żywności i Leków, ang. Food and Drug Administration). Przeciwciała blokują PD-1 i CTLA4, prowadząc do wzmocnienia aktywności limfocytów T względem komórek nowotworowych [38]. W ostatnich latach badacze odkryli kolejne punkty kontrolne stanowiące cele immunoterapeutyczne w leczeniu HNSCC, są to: LAG3 (ang, Lymphocyte-Activation Gene 3), TIM3 (ang. T-cell Immunoglobulin and Mucin-Domain Containing-3) oraz receptor KIR (ang. Killer-cell Immunoglobulin-like Receptor) [39, 40, 41]. Wszystkie wymienione punkty kontrolne wchodzą w skład sygnałów inhibitorowych. $\mathrm{W}$ ich obecności dochodzi do anergii lub apoptozy limfocytów $\mathrm{T}$, co w dalszej perspektywie wiąże się z osłabieniem odpowiedzi immunologicznej [8].

Istotne znaczenie w rozwoju HNSCC mają nie tylko ścieżki inhibitorowe, ale również kostymulatorowe. Najczęściej opisywaną ścieżkąjest CD28/B7, jednak stymulujących oddziaływań jest więcej: CD137/CD137-L, OX40/OX40-L oraz CD40/CD-40L. Cechą charakterystyczną wymienionych powyżej receptorów jest ich zdolność do wiązania czynnika martwicy nowotworu TNF (ang. Tumor Necrosis Factor). Związanie TNF z receptorem ma wpływ na aktywność limfocytów i może prowadzić do apoptozy komórek nowotworowych [42]. U chorych z HNSCC obserwuje się obniżoną ekspresję receptorów stymulatorowych na powierzchni limfocytów T, co koreluje z cięższą postacią choroby [43]. Wydaje się zatem, że blokowanie sygnałów koinhibitorowych i pobudzanie sygnałów kostymulatorowych może być skuteczną metodą terapeutyczną w leczeniu HNSCC. Wiele przeciwciał monoklonalnych nakierowanych na omówione powyżej szlaki sygnałowe zostało już opracowanych, a ich działanie ma na celu wywołanie immunologicznej odpowiedzi przeciwnowotworowej.

\section{Podsumowanie}

Immunologia nowotworów stanowi szybko rozwijającą się dziedzinę nauki, jednak jeszcze wiele aspektów oddziaływań pomiędzy nowotworem, a układem immunologicznym pozostaje niezbadanych. Komórki nowotworowe wykorzystują liczne mechanizmy, które umożliwiają im ucieczkę spod kontroli układu odpornościowego. Mutacje występujące w elementach kompleksu HLA oraz maszynerii APM są powszechne w przebiegu HNSCC oraz związane z cięższym przebiegiem choroby. Co więcej u chorych na płaskonabłonkowy nowotwór regionu głowy i szyi występuje szereg mutacji powodujących zaburzenia w funkcjonowaniu różnych sygnałów kostymulatorowych oraz koinhibitorowych, których zadaniem jest pobudzanie albo hamownie działania układu immunologicznego. Dalsze badanie tła molekularno-immunologicznego HNSCC oraz rozmieszczenia komórek odpornościowych w mikrośrodowisku guza jest kluczowe dla opracowania nowych schematów immunoterapeutycznych.

\section{Konflikt interesu / Conflict of interest}

Nie występuje / None 


\section{Finansowanie / Financial support}

Praca była finansowana ze środków Wielkopolskiego Centrum Onkologii (grant nr 9/01/2018/PRB/ WCO/oo3) oraz Uniwersytetu Medycznego w Poznaniu (grant nr 502-14-22113300-41277).

\section{Etyka / Ethics}

Treści przedstawione w artykule są zgodne z zasadami Deklaracji Helsińskiej, dyrektywami UE oraz ujednoliconymi wymaganiami dla czasopism biomedycznych.

\section{Piśmiennictwo / References}

[1] R. J. Sanderson i J. A. Ironside, “Squamous cell carcinomas of the head and neck,” BMJ, no. 325(7368): 822-827, 2002.

[2] The Cancer Genome Atlas Network, "Comprehensive genomic characterization of head and neck squamous cell carcinomas," Nature, vol. 517, no. 576-582, 2015.

[3] Y. Suh, I. Amellio, T. Guerrero Urbano i M. Tavassoli, "Clinical update on cancer: molecular oncology of head," Cell Death and Disease, 2014.

[4] S. M. Thomas i J. R. Grandis, "The current state of head and neck cancer gene therapy.," Human Gene Therapy, pp. 1565-1575, 2009.

[5] L. Vidal i G. Maura, "Human Papillomavirus in HNSCC: Recognition of a Distinct Disease Type," Hematology/Oncology Clinics of North America, pp. 1125-1142, 2008.

[6] L. Licitra, G. Zigon, G. Gatta, M.-J. Sanchez, F. Berrino, "Human Papillomavirus in HNSCC: A European Epidemiologic Perspective," Hematology/Oncology Clinics of North America, pp. 1143-1153, 2008.

[7] J. M. Moskovitz i R. L. Ferris, "Tumor Immunology, Immunotherapy and Its Application to Head and Neck Squamous Cell Carcinoma (HNSCC)," Critical Issues in Head and Neck Oncology, no. 341-355, 2018.

[8] J. D. Moy, J. M. Moskovitz, R. L. Ferris, "Biological mechanisms of immune escape and implications for immunotherapy in head and neck squamous cell carcinoma," European Journal of Cancer, pp. 152-166, 2017.

[9] A. Jebreel, D. Mistry, D. Loke, "Investigation of interleukin 10, 12 and 18 levels in patients with head and neck cancer.," J Laryngol Otol, pp. 121:246-252, 2007.

[10] N. M. Moutsopoulos, J. Wen, S. M. Wahl, “TGF-beta and tumors: An ill-fated alliance," Curr Opin Immunol, pp. 20: 234-240, 2008.

[11] Kuss, B. Hathaway, R. L. Ferris, W. Gooding, T. L. Whiteside, "Decreased absolute counts of Tlymphocyte subsets and their relation to disease in squamous cell carcinoma of the head and neck.," Clinical cancer research, pp. 3755-3762, 2004.

[12] T. Bauernhofer, I. Kuss, B. Henderson, . A. S. Baum, T. L. Whiteside, "Preferential apoptosis of CD56dim natural killer cell subset in patients with cancer.," European journal of immunology, pp. 119-124, 2003.

[13] S. Dasgupta, M. Bhattacharya-Chatterjee, B. W. O'Malley, S. K. Chatterjee, "Inhibition of NK Cell Activity through TGF- $\beta 1$ by Down-Regulation of NKG2D in a Murine Model of Head and Neck Cancer," Journal of Immunology, pp. 5541-5550, 2005.

[14] A. López-Albaitero, J. V. Nayak, T. Ogino, A. Machandia, W. Gooding, . A. B. DeLeo, S. Ferrone, R. L. Ferris, "Role of antigen-processing machinery in the in vitro resistance of squamous cell carcinoma of the head and neck cells to recognition by CTL.,” Journal of Immunology, pp. 3402-3409, 2006.

[15] R. L. Ferris, T. L. Whiteside, S. Ferrone, "Immune Escape Associated with Functional Defects in AntigenProcessing Machinery in Head and Neck Cancer," Clin Cancer Res, pp. (13) 3890-3895, 2006

[16] J. D. Schoenfeld, “ Immunity in head and neck cancer,” Cancer Immunol Res , pp. 12-17, 2015

[17] M. Frisch, R. J. Biggar, E. A. Engels, J. J. Goedert, AIDS-Cancer Match Registry Study Group, "Association of cancer with AIDSrelated immunosuppression in adults.," JAMA, pp. 285: 1736-1745, 2001.

[18] A. E. Grulich, M. T. van Leeuwen, M. O. Falster, C. M. Vajdic , "Incidence of cancers in people with HIV/ AIDS compared with immunosuppressed transplant recipients: a meta-analysis,” Lancet, pp. 370: 59- 
67, 2007.

[19] S. A. Birkeland, H. H. Storm, L. U. Lamm, L. Barlow, I. Blohmé, B. Forsberg, B. Eklund, O. Fjeldborg, M. Friedberg, l. Frödin, "Cancer risk after renal transplantation in the Nordic countries, 1964-1986," International Journal of Cancer, pp. 60:183-189, 1995.

[20] V. Varilla , J. Atienza, C. A. Dasanu, " Immune alterations and immunotherapy prospects in head and neck cancer.,” Expert Opin Biol Ther, pp. 1241-56, 2013.

[21] R. D. Schreiber, L. J. Old, M. J. Smyth, “Cancer Immunoediting: Integrating Immunity's Roles in Cancer Suppression and Promotion,” Science, pp. 1565-1570, 2011.

[22] F. Concha-Bravente, R. M. Srivastava, S. Trivedi, Y. Lei, U. Chandran, R. R. Seethala, "Identification of the cell intrinsic and -extrinsic pathways downstream of EGFR and IFNgamma that induce PD-L1 expression in head and neck cancer," Cancer Res, pp. 1031-43, 2016.

[23] M. Meissner, T. E. Reichert, M. Kunkel, W. Gooding, T. L. Whiteside, S. Ferrone, B. Seliger, "Defects in the Human Leukocyte Antigen Class I Antigen Processing Machinery in Head and Neck Squamous Cell Carcinoma: Association with Clinical Outcome," Clinical Cancer Research, pp. 2552-60, 2005.

[24] R. L. Ferris, "Immunology and Immunotherapy of Head and Neck Cancer," Journal of Clinical Oncology, pp. 3293-3304, 2015.

[25] The Cancer Genome Atlas Network, "Comprehensive genomic characterization of head and neck squamous cell carcinomas.," Nature, pp. 517(7536):576-82, 2015.

[26] A. López-Albaitero, . J. V. Nayak, T. Ogino, A. Machandia, W. Gooding, A. B. DeLeo, S. Ferrone, R. L. Ferris, "Role of antigen-processing machinery in the in vitro resistance of squamous cell carcinoma of the head and neck cells to recognition by CTL.," J Immunol , pp. 176 (6) 3402-3409, 2006.

[27] C. Badoual, F. Sandoval, H. Pere, S. Hans, A. Gey, N. Merillon, C. Van Ryswick, F. Quintin-Colonna, P. Bruneval , D. Brasnu, W. H. Fridman, E. Tartour, "Better understanding tumor-host interaction in head and neck cancer to improve the design and development of immunotherapeutic strategies," Head \& Neck, pp. 946-958, 2010.

[28] M. S. Leibowitz, P. A. Filho, S. Ferrone, R. L. Ferris, "Deficiency of activated STAT1 in head and neck cancer cells mediates TAP1-dependent escape from cytotoxic T lymphocytes.," Cancer Immunol Immunother, pp. 525-535, 2016.

[29] T. Ogino, H. Shigyo, H. Ishii, A. Katayama, N. Miyokawa, Y. Harabuchi, S. Ferrone, "HLA class I antigen down-regulation in primary laryngeal squamous cell carcinoma lesions as a poor prognostic marker.," Cancer Res, pp. (18) 9281-9289, 2006.

[30] F. Concha-Benavente, R. M. Srivastava, S. Ferrone, R. L. Ferris, "EGFR-mediated tumor immunoescape: The imbalance between phosphorylated STAT1 and phosphorylated STAT3," Oncoimmunology, p. 2(12):e27215, 2013.

[31] M. S. Leibowitz, R. M. Srivastava, P. A. Andrade Filho, A. M. Egloff, L. Wang, R. R. Seethala, S. Ferrone, R. L. Ferris, "SHP2 is overexpressed and inhibits pSTAT1-mediated APM component expression, T cell attracting chemokine secretion, and CTL recognition in head and neck cancer cells," Clin Cancer Res., pp. 19(4):798-808, 2013.

[32] K. Mimura, K. Shiraishi,, A. Mueller, S. Izawa, L.-F. Kua, J. So, W.-P. Yong, H. Fujii, B. Seliger, R. Kiessling, K. Kono, "The MAPK Pathway Is a Predominant Regulator of HLA-A Expression in Esophageal and Gastric Cancer," The Journal of Immunology, p. 191(12): 6261-6272., 2013.

[33] B. P. Pollack, B. Sapkota, T. V. Cartee, "Epidermal growth factor receptor inhibition augments the expression of MHC class I and II genes.," Clin Cancer Res., pp. (13):4400-13, 2011.

[34] R. M. Srivastava, S. Trivedi, F. Concha-Benavente, J. Hyun-Bae, L. Wang, R. R. Seethala, B. F. Branstetter, S. Ferrone, R. L. Ferris, "STAT1-Induced HLA Class I Upregulation Enhances Immunogenicity and Clinical Response to Anti-EGFR mAb Cetuximab Therapy in HNC Patients.," Cancer Immunol Res., pp. (8) 936-45, 2015

[35] S. Trivedi, F. Concha-Benavente, R. M. Srivastava, H. B. Jie, S. P. Gibson, N. C. Schmitt, R. L. Ferris, "Immune biomarkers of anti-EGFR monoclonal antibody therapy," Annals of Oncology, pp. 40-47, 2015.

[36] E. V. Fletcher, L. Love-Homan, A. Sobhakumari , C. R. Feddersen , A. T. Koch, A. Goel, A. L. Simons, "EGFR inhibition induces proinflammatory cytokines via NOX4 in HNSCC." Molecular Cancer 
Research, pp. (12):1574-84, 2013.

[37] H. von Boehmer i F. Melchers, "Checkpoints in lymphocyte development and autoimmune disease," Nature Immunology, pp. 14-20, 2010.

[38] K. C. Ohaegbulam, A. Assal, E. Lazar-Molnar, Y. Yao, X. Zang, "Human cancer immunotherapy with antibodies to the PD-1 and PD-L1 pathway," Trends in Molecular Medicine, pp. 24-33, 2015.

[39] C. Camisaschi, A. De Filippo, V. Beretta, B. Vergani, A. Villa, E. Vergani, "Alternative Activation of Human Plasmacytoid DCs In Vitro and in Melanoma Lesions: Involvement of LAG-3," Journal of Investigative Dermatology, pp. 1893-1902, 2014.

[40] K. Sakuishi, L. Apetoh, J. M. Sullivan, B. R. Blazar, V. K. Kuchroo, A. C. Anderson, "Targeting Tim-3 and PD-1 pathways to reverse T cell exhaustion and restore anti-tumor immunity," JEM, p. (10): 2187, 2010.

[41] R. Mandal, Y. Senbabaoglu, A. Desrichard, J. J. Havel, M. G. Dalin, N. Riaz, "The head and neck cancer immune landscape and its immunotherapeuticimplications," JCI Insight, p. 1:e89829.doi:10.1172/jci. insight. 89829, 2016.

[42] P. Baruah, M. Lee, T. Odutoye, P. Williamson, N. Hyde, J. C. Kaski, I. E. Dumitriu, "Decreased levels of alternative co-stimulatory receptors $\mathrm{OX} 40$ and 4-1BB characterise $\mathrm{T}$ cells from head and neck cancer patients.," Immunobiology, p. 217(7):669-75, 2012.

[43] , Simone C.B et al. Multi- Institutional prospective study of reirradiation with proton beam radiotherapy for locoregionally recurrent non-small lung cancer. J.Thorac Oncol. 2017.12(2);281-292. 